\title{
EFFECT OF AGE ON VARIATION IN PHYSICAL AND MECHANICAL PROPERTIES OF Acacia mangium PLANTED IN THAI NGUYEN
}

\author{
Duong Van Doan ${ }^{1 *}$, Nguyen Van Thai ${ }^{1}$, Khong Van Manh ${ }^{2}$ \\ ${ }^{1} T N U$ - University of Agriculture and Forestry \\ ${ }^{2}$ Phu Luong Administration of Forestry
}

\begin{tabular}{|c|c|}
\hline ART & \multirow{13}{*}{ 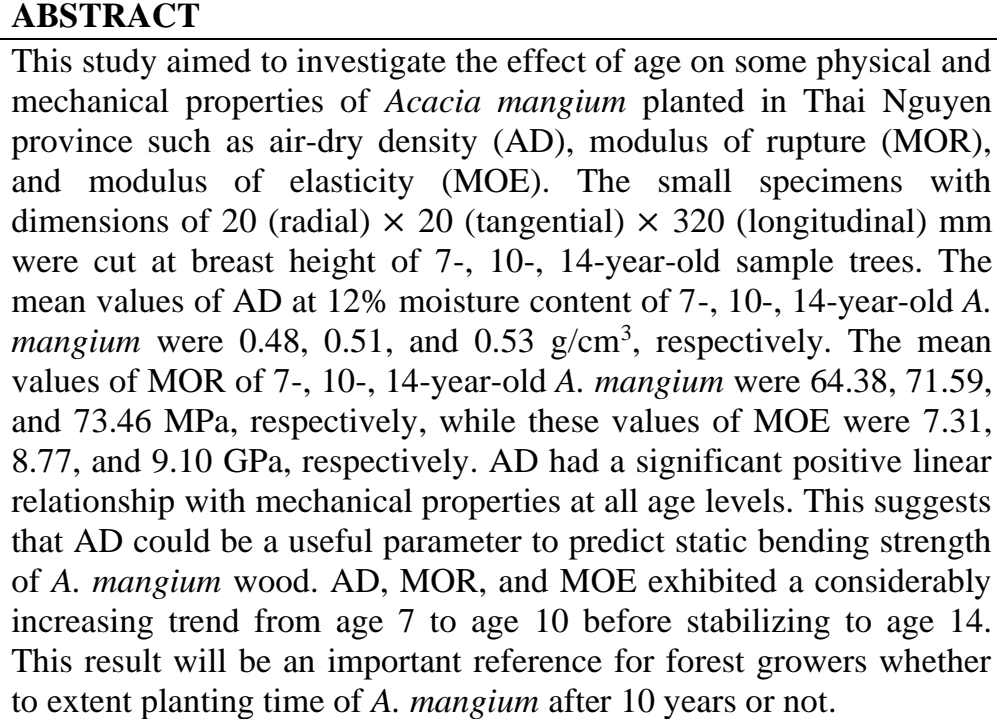 } \\
\hline Received: $08 / 10 / 2020$ & \\
\hline Revised: 06/01/2021 & \\
\hline Published: 14/01/2021 & \\
\hline & \\
\hline KEYWORDS & \\
\hline Wood science & \\
\hline Acacia mangium & \\
\hline Air-dry density & \\
\hline & \\
\hline Tree age & \\
\hline MOE & \\
\hline MOR & \\
\hline
\end{tabular}

\section{ẢNH HƯởNG CỦA TUỔI ĐẾN SỰ BIẾN ĐỔI CÁC TÍNH CHẤT VẠTT LÝ VÀ CƠ HỌC CỦA GỖ KEO TAI TƯợNG (Acacia mangium) TRỒNG TẠI THÁI NGUYÊN}

\author{
Dương Văn Đoàn ${ }^{1 *}$, Nguyễn Văn Thái ${ }^{1}$, Khổng Văn Mạnh ${ }^{2}$ \\ ${ }^{1}$ Truờng Đại học Nông Lâm - ĐH Thái Nguyên \\ ${ }^{2}$ Hạt Kiểm lâm huyện Phú Luoong, tỉnh Thái Nguyên
}

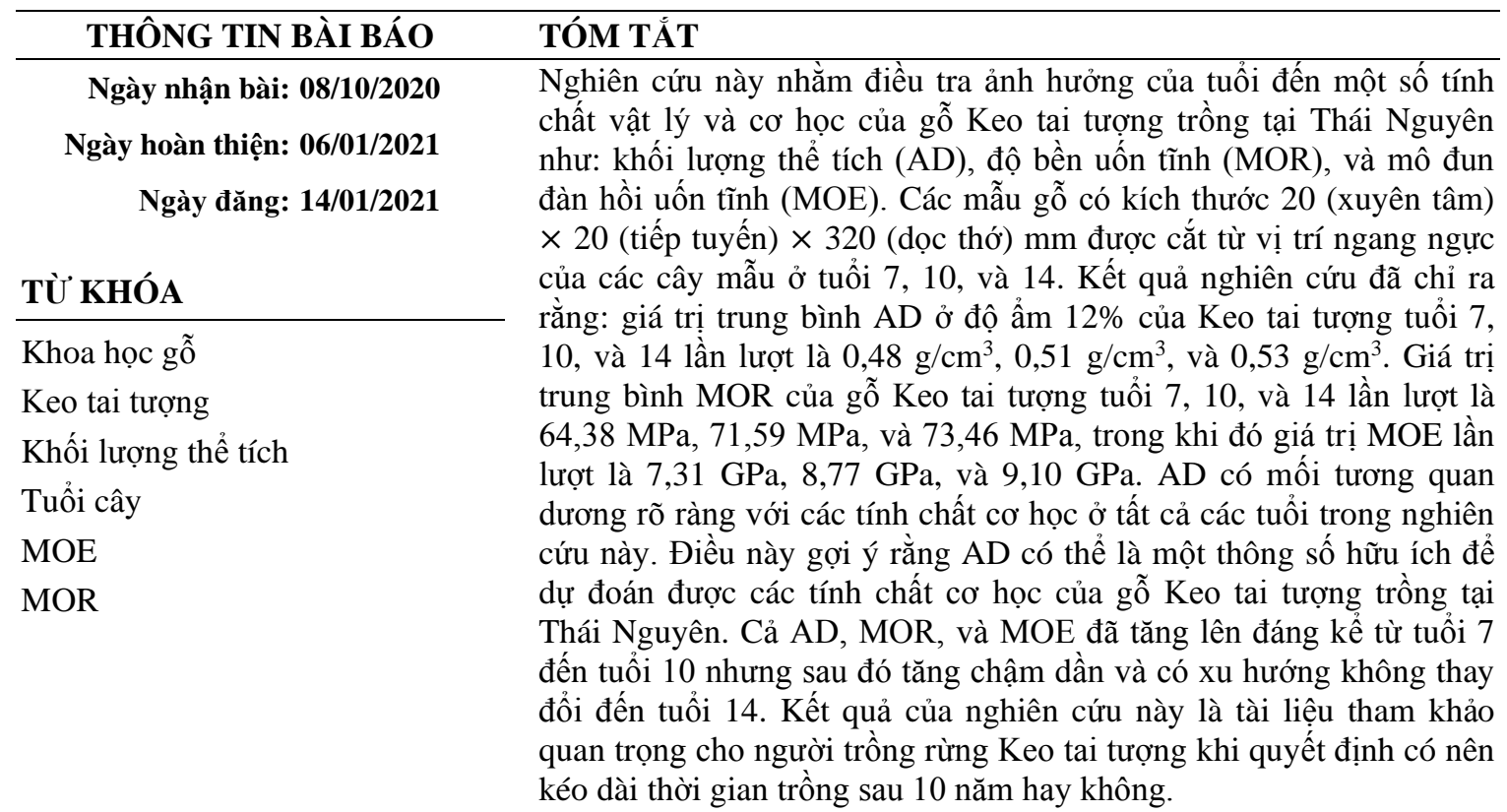

DOI: https://doi.org/10.34238/tnu-jst.3689

\footnotetext{
${ }^{*}$ Corresponding author. Email: duongvandoan@tuaf.edu.vn
} 


\section{Introduction}

Acacia mangium Willd. is one of the important tree species planted popularly in Vietnam because of its wide applicability with a variety of forest sites, straight stem, and faster growth than Acacia auriculiformis and Uro Eucalyptus [1]. According to the documentary No. 30/2018/TT-BNNPTNT of the Ministry of Agriculture and Rural Development issued on November 16, 2018 about the list of major forestry plant species, A. mangium is classified into the list of the main species for planting forest in Vietnam [2]. Currently, A. mangium wood is mainly used as raw materials for pulp production, particle board, MDF board, and peeled veneers [3]. A. mangium is a fast-growing species that produces low wood quality because of the present of juvenile wood, which can cause serious problems [4].

Age of tree is one of the important factors affecting to variation in wood properties. The trend of variation depends on some factors such as species, growth conditions, and age of tree. There were some studies regarding to evaluate the effect of age on variation in wood properties of $A$. mangium. Makino et al. [4] evaluated the wood properties of 5- and 7-year-old A. mangium planted in West Java, Indonesia. The mean basic density and compression strength for 5-year-old trees were $0.42 \mathrm{~g} / \mathrm{cm}^{3}$ and $30.0 \mathrm{MPa}$, and for 7 -year-old trees were $0.45 \mathrm{~g} / \mathrm{cm}^{3}$ and $32.8 \mathrm{MPa}$, respectively. Chowdhury et al. [5] studied the effects of age (10-, 15-, and 20-year-old) on physical properties of $A$. mangium trees grown in Bangladesh. The authors reported that the mean basic density of $A$. mangium among different age groups was $0.52-0.60 \mathrm{~g} / \mathrm{cm}^{3}$, the maximum being observed in wood from 20 -y-old trees and the minimum in wood from 10-year-old trees. In Vietnam, the researches reporting effect of age on variation in physical and mechanical properties of A. mangium wood is limited. Trinh [3] reported effect of harvested age on some physical and mechanical properties of peeled veneer of A. mangium. This study showed that the basic density of the peeled veneers increased with the age of the trees. The mean basic density and modulus of elasticity of A. mangium peeled veneers at the age of $6,9,14$ were $0.39,0.43$, and $0.51 \mathrm{~g} / \mathrm{cm}^{3}$ for basic density, respectively and $8.66,10.87$, and $10.93 \mathrm{GPa}$ for modulus of elasticity, respectively.

Information on wood structure and properties, and the influence of tree age on these, is required for better utilisation. In this study, we assessed the effects of tree age on some physical and mechanical properties of A. mangium trees planted in Thai Nguyen, Vietnam. The results of this study provide information to forest growers for selecting approximate time to harvest $A$. mangium wood.

\section{Materials and Methods}

\subsection{Materials}

A total of fifteen trees of 7-, 10-, and 14-year-old A. mangium planted in Phu Luong, Thai Nguyen, Vietnam was collected in this study (5 trees/age level). The latitude and longitude of 7-, 10-, and 14-y-old planted forests are N02408224 and E00417280, N02402724 and E00414187, N02402646 and E00414070, respectively. The sample trees were selected basing on straight trunks, normal branching, and no signs of any diseases or pest symptoms. Diameter at breast height (1.3 $\mathrm{m}$ above the ground) as well as the total stem height for each tree was measured. The detail information of each tree is given in Table 1. The north and south sides of each tree were marked before felling.

Method of cutting specimens for experiments is presented in Figure 1. From each tree, 50-cmlong logs were cut from 1.05 to $1.55 \mathrm{~m}$ height from above the ground and air-dried in two months. From each $\log$, small specimens $(20 \times 20 \times 320 \mathrm{~mm}$, Radial $\times$ Tangential $\times$ Longitudinal) were cut at three distances from pith $(10,50$, and $90 \%$ of the radial length from pith) on four sides (north, south, east, west) for measuring air-dry density (AD), modulus of rupture (MOR), and modulus of elasticity (MOE) as described in Figure 1. For 7-year-old trees, in each radial direction, small specimens were only cut at two positions: near the pith and near 
the bark corresponding to 10 and $90 \%$ radial positions because of small diameter. The specimens were conditioned in a room at a constant temperature $\left(20^{\circ} \mathrm{C}\right)$ and relative humidity $(60 \%)$ to constant weight.

Table 1. Diameter and height of sample trees

\begin{tabular}{|c|c|c|}
\hline Trees & $D_{1.3}(\mathrm{~cm})$ & $\mathbf{H}_{\mathrm{vn}}(\mathrm{m})$ \\
\hline \multicolumn{3}{|l|}{ Age 7} \\
\hline 1 & 14.0 & 14.0 \\
\hline 2 & 15.6 & 16.0 \\
\hline 3 & 16.6 & 15.0 \\
\hline 4 & 17.2 & 17.5 \\
\hline 5 & 15.9 & 17.0 \\
\hline \multicolumn{3}{|l|}{ Age 10} \\
\hline 6 & 23.1 & 17.5 \\
\hline 7 & 24.6 & 16.8 \\
\hline 8 & 25.3 & 16.2 \\
\hline 9 & 23.9 & 18.6 \\
\hline 10 & 22.7 & 19.8 \\
\hline \multicolumn{3}{|l|}{ Age 14} \\
\hline 11 & 18.8 & 16.2 \\
\hline 12 & 24.2 & 16.5 \\
\hline 13 & 27.4 & 17.0 \\
\hline 14 & 24.5 & 21.0 \\
\hline 15 & 23.6 & 20.4 \\
\hline
\end{tabular}

Note: $D_{1.3}$ - diameter at breast height (at $1.3 \mathrm{~m}$ above the ground), $H_{v n}$-tree height

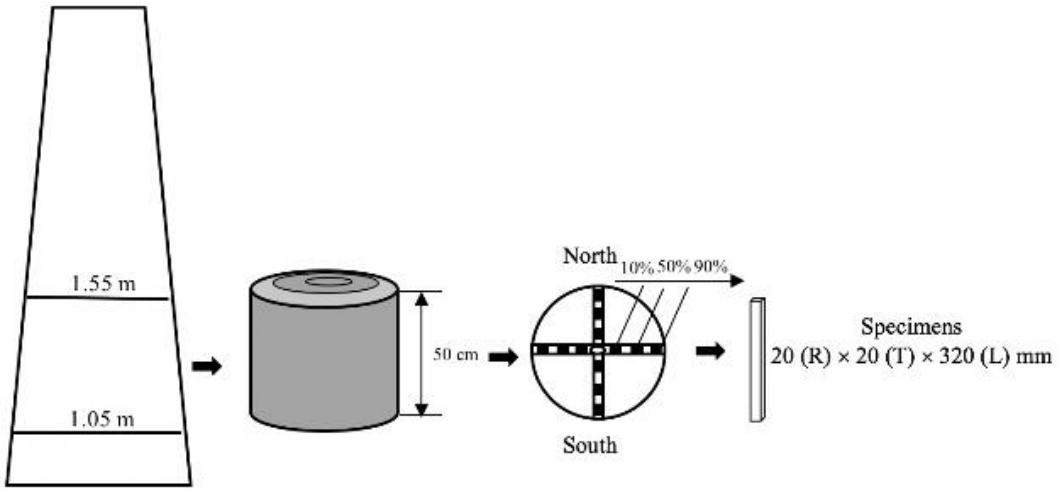

Figure 1. Method of cutting specimens for experiment from each tree

\subsection{Measuring wood properties}

$\mathrm{AD}, \mathrm{MOR}$, and $\mathrm{MOE}$ were assessed in accordance with Vietnamese Industrial Standards (TCVN) as described by Duong et al. [6]. AD was determined in according TCVN 8048-2:2009 (ISO 3131:1975), while MOR and MOE were measured in according to TCVN 8048-3:2009 (3133:1975) and TCVN 8048-4:2009 (ISO 3349:1975), respectively. Twenty samples were randomly chosento test moisture content (MC) after measuring mechanical properties. The average MC of the test specimens was $12 \pm 0.18 \%$.

\subsection{Data analysis}

The data in this study was analysed by using the R software (R Core Team) version 4.0.2 [7]. Tukey-Kramer HSD test was used for comparing wood properties among the age groups.

\section{Results and Discussions}




\subsection{Variation in $A D$ from the pith to bark}

Table 2 presents the mean values of $\mathrm{AD}$ at 10,50 , and $90 \%$ radial length from the pith to bark in trees of Acacia mangium 7-, 10-, and 14-year-old planted in Thai Nguyen. Results of ANOVA analysis are also presented in Table 2 to exam that there are significant differences in AD among radial positions or not.

The mean AD for 7-, 10-, and 14-y-old trees varied from 0.45 to $0.51 \mathrm{~g} / \mathrm{cm}^{3}, 0.47$ to 0.54 $\mathrm{g} / \mathrm{cm}^{3}$, and 0.48 to $0.56 \mathrm{~g} / \mathrm{cm}^{3}$, respectively (at MC $12 \%$ ). The findings of the present study are in agreement to those in literature. Phi [1] reported an $\mathrm{AD}$ of $0.43-0.56 \mathrm{~g} / \mathrm{cm}^{3}$ of A. mangium grown in Binh Duong, Vietnam. In addition, Chowhury et al. [5] reported the mean AD of 10year-old A. mangium planted in Bangladesh was $0.52 \mathrm{~g} / \mathrm{cm}^{3}$ that is similar with AD observed for trees of age 10 in this study.

Table 2. Mean of air-dry density $\left(\mathrm{g} / \mathrm{cm}^{3}\right)$ and results of statistical analysis among radial positions in different ages

\begin{tabular}{ccccc}
\hline \multirow{2}{*}{ Age } & \multicolumn{3}{c}{ Radial position (\%) } & \multirow{2}{*}{ p-value } \\
\cline { 2 - 4 } & $\mathbf{1 0}$ & $\mathbf{5 0}$ & $\mathbf{9 0}$ & $* * *$ \\
\hline 7 & $0.45^{\mathrm{b}} \pm 0.04$ & & $0.51^{\mathrm{a}} \pm 0.02$ & $* * *$ \\
10 & $0.47^{\mathrm{b}} \pm 0.05$ & $0.53^{\mathrm{a}} \pm 0.03$ & $0.54^{\mathrm{a}} \pm 0.03$ & $* * *$ \\
\hline 14 & $0.48^{\mathrm{b}} \pm 0.05$ & $0.55^{\mathrm{a}} \pm 0.03$ & $0.56^{\mathrm{a}} \pm 0.03$ & $* 3$ \\
\hline
\end{tabular}

Note: ${ }^{a, b, c}$ Mean with different superscript within a row significant difference; $* * *: p<0.001$

The result of ANOVA analysis showed that AD for 7-y-old A. mangium wood was the lowest near the pith and the highest near the bark. In 10- and 14-y-old trees, the radial variation pattern for $\mathrm{AD}$ was similar. $\mathrm{AD}$ increased rapidly from the pith to position of $50 \%$ radial length before becoming constant towards the bark (Table 2). The radial pattern of variation from pith to periphery of $\mathrm{AD}$ has been reported for A. mangium wood. Makino et al. [4] reported the radial variation for basic density of 5- and 7-y-old A. mangium trees planted in Indonesia. Basic density gradually increased to about $6 \mathrm{~cm}$ from the pith before stabilizing. Kim et al. [8] reported a similar pattern of $\mathrm{AD}$ for Acacia hybris planted in northern Vietnam. On other hand, Wahyudi et al. [9] reported a nearly constant basic density of Azadirachta excelsa from pith to bark. Based on the present results and previous reports, radial variation of AD depends on species.

\subsection{Radial variations in mechanical properties}

Table 3 presents the mean mechanical properties at 10,50, and 90\% radial length from the pith of 7-, 10-, and 14-year-old A. mangium trees planted in Thai Nguyen. The mean MOR for 7year-old trees at 10 and $90 \%$ radial length was 56.73 and $73.05 \mathrm{MPa}$. The mean MOR for 10- and 14-year-old trees varied from 61.94 to $76.16 \mathrm{MPa}$ and from 65.13 to $77.99 \mathrm{MPa}$, respectively. Obtained results in the present study were similar to those in previous studies. Shari et al. [10] investigated the static bending strength of 6-y-old A. mangium trees planted in different sites. This study reported that the overall MORs of A. mangium planted in Indonesia, Malaysia, and Thailand were $75.02,68.15$, and $80.54 \mathrm{MPa}$, respectively.

The mean MOE for 7-, 10-, and 14-year-old varied from 6.56 to $8.17 \mathrm{GPa}, 7.45$ to $9.55 \mathrm{GPa}$, and 7.75 to $10.14 \mathrm{GPa}$, respectively. Shari et al. [10] also reported that the mean MOE of 6-y-old A. mangium trees planted in Indonesia, Malaysia, and Thailand were 6.73, 6.29, and 6.17 GPa, respectively. 
Table 3. Mean of mechanical properties and results of statistical analysis among radial positions in different ages

\begin{tabular}{|c|c|c|c|c|c|}
\hline \multirow{2}{*}{ Mechanical properties } & \multirow{2}{*}{ Age } & \multicolumn{3}{|c|}{ Radial position from pith (\%) } & \multirow{2}{*}{ p-value } \\
\hline & & 10 & 50 & 90 & \\
\hline \multirow{3}{*}{ MOR (MPa) } & 7 & $56.73^{\mathrm{b}} \pm 11.14$ & & $73.05^{\mathrm{a}} \pm 6.47$ & $* * *$ \\
\hline & 10 & $61.94^{\mathrm{b}} \pm 14.67$ & $76.39^{a} \pm 11.96$ & $76.16^{\mathrm{a}} \pm 10.00$ & $* *$ \\
\hline & 14 & $65.13^{\mathrm{b}} \pm 15.62$ & $77.75^{\mathrm{a}} \pm 13.30$ & $77.99^{\mathrm{a}} \pm 9.98$ & $* *$ \\
\hline \multirow{3}{*}{$\begin{array}{l}\mathrm{MOE} \\
(\mathrm{GPa})\end{array}$} & 7 & $6.56^{\mathrm{b}} \pm 0.71$ & & $8.17^{\mathrm{a}} \pm 0.94$ & $* * *$ \\
\hline & 10 & $7.45^{\mathrm{b}} \pm 1.26$ & $9.29^{\mathrm{a}} \pm 1.07$ & $9.55^{\mathrm{a}} \pm 0.65$ & $* * *$ \\
\hline & 14 & $7.75^{\mathrm{b}} \pm 1.10$ & $9.55^{\mathrm{a}} \pm 1.07$ & $10.14^{\mathrm{a}} \pm 0.88$ & $* * *$ \\
\hline
\end{tabular}

Note: Note: ${ }^{a, b, c}$ Mean with different superscript within a row significant difference;

$* *: p<0.01 ; * * *: p<0.001$

The radial variation patterns for MOR and MOE were similar to those for AD (Table 3). In age of 7 , the result of statistical analysis showed that there was a significant difference in MOR between two positions (near the pith and near the bark). In 10- and 14-y-old trees, MOR and MOE increased considerably to the middle position before remaining constant value forward to outside (Table 3). Fujimoto et al. [11] reported that the compression strength increased from the pith to $5 \mathrm{~cm}$, after which it was almost constant in 30-y-old A. mangium. This pattern is also seen in other hardwood species. Machado et al. [12] investigated the radial variation in MOR and MOE of Acacia melanoxylon wood. Authors showed that MOR and MOE increased rapidly from pith to $50 \%$ radial position before stabilizing. This trend may be contributable to the thicker walls of fibers in the mature wood than those in the juvenile wood.

\subsection{Effect of age on variation in $A D, M O R$, and $M O E$}

The mean AD for 7-, 10-, and 14-y-old A. mangium trees was $0.48,0.51$, and $0.53 \mathrm{~g} / \mathrm{cm}^{3}$, respectively (Table 4). The AD increased with increasing tree age. The average AD of 14-yearold trees increased about 4\% compared to that of 10-year-old trees and about 10\% compared 7year-old trees. However, the analysis of variance indicated that, there is only significant difference between $\mathrm{AD}$ of age 7 and $\mathrm{AD}$ of age 10 and 14, while no significant difference was found between $\mathrm{AD}$ of age 10 and $\mathrm{AD}$ of age 14 .

Table 4. Physical and mechanical properties in different ages, ANOVA, and Tukey test results

\begin{tabular}{ccccc}
\hline Wood & \multicolumn{3}{c}{ Age } & \multirow{2}{*}{-value } \\
\cline { 2 - 5 } properties & $\mathbf{7}$ & $\mathbf{1 0}$ & $\mathbf{1 4}$ & $* * *$ \\
$\mathrm{AD}\left(\mathrm{g} / \mathrm{cm}^{3}\right)$ & $0.48^{\mathrm{b}} \pm 0.04$ & $0.51^{\mathrm{a}} \pm 0.05$ & $0.53^{\mathrm{a}} \pm 0.05$ & $* *$ \\
$\mathrm{MOR}(\mathrm{MPa})$ & $64.38^{\mathrm{b}} \pm 10.55$ & $71.59^{\mathrm{a}} \pm 13.92$ & $73.46^{\mathrm{a}} \pm 14.44$ & $* *$ \\
$\mathrm{MOE}(\mathrm{GPa})$ & $7.31^{\mathrm{b}} \pm 1.15$ & $8.77^{\mathrm{a}} \pm 1.38$ & $9.10^{\mathrm{a}} \pm 1.43$ & \\
\hline
\end{tabular}

Note: ${ }^{a, b, c}$ Mean with different superscript within a row significant difference;

**: $p<0.01$; ***: $p<0.001$

The mean MOR for 7-, 10-, and 14-y-old A. mangium trees was 64.38, 71.59, and 73.46 MPa, respectively. The mean MOE for 7-, 10-, and 14-y-old A. mangium trees was 7.31, 8.77, and 9.10 $\mathrm{GPa}$, respectively (Table 4). The analysis of variance also indicated that there was no significant difference in MOR and MOE between age 10 and age 14, while tree age did have a significant effect to MOR and MOE from 7 to 10 years. The results in this study will be an important reference for forest growers whether to extent planting time of $A$. mangium after 10 years or not.

\subsection{The relationship between $A D$ and mechanical properties}

Coefficients of correlations ( $r$ ) for relationship between $\mathrm{AD}$ and mechanical properties of $A$. mangium planted in Thai Nguyen are summarized in Table 5. AD had significant $(p<0.001)$ 
positive linear correlations with MOR in all age levels. Correlation coefficient between AD and MOR is 0.72 when combined ages (Figure 2). AD had also significant positive linear relationships at the 0.001 confidence level with MOE in all age levels (Table 5). For combined ages, the value of correlation coefficient between $\mathrm{AD}$ and MOE is 0.78 (Figure 3). The above results suggest that $\mathrm{AD}$ can be considered to be a powerful indicator for predicting the static bending strength of A. mangium planted in Thai Nguyen. Prediction models of mechanical properties (MOR, MOE) for A. mangium clear wood in different ages and combined ages are presented in Table 5.

Table 5. Prediction models of static properties (MOR, MOE) for Acacia mangium wood

\begin{tabular}{ccccc}
\hline Modelling & Age & Equation & $\boldsymbol{r}$ & $\boldsymbol{p}$-value \\
\hline & 7 & MOR $=210.89 \times \mathrm{AD}-36.05$ & 0.79 & $* * *$ \\
MOR $(\mathrm{MPa})$ & 10 & $\mathrm{MOR}=243.99 \times \mathrm{AD}-53.74$ & 0.82 & $* * *$ \\
$(\sim \mathrm{AD})$ & 14 & $\mathrm{MOR}=156.61 \times \mathrm{AD}-9.54$ & 0.65 & $* * *$ \\
& Combined ages & MOR $=\mathbf{1 9 3 . 4 4} \times \mathrm{AD}-\mathbf{2 8 . 2 8}$ & 0.72 & $* * *$ \\
\hline & 7 & $\mathrm{MOE}=21.20 \times \mathrm{AD}-2.78$ & 0.73 & $* * *$ \\
$\mathrm{MOE}(\mathrm{GPa})$ & 10 & $\mathrm{MOE}=21.95 \times \mathrm{AD}-2.50$ & 0.75 & $* * *$ \\
$(\sim \mathrm{AD})$ & 14 & $\mathrm{MOE}=20.13 \times \mathrm{AD}-1.57$ & 0.72 & $* * *$ \\
& Combined ages & MOE $=\mathbf{2 3 . 0 5} \times \mathbf{A D}-\mathbf{3 . 2 2}$ & 0.78 & $* * *$ \\
\hline
\end{tabular}

Note: $* * *: p<0.001$

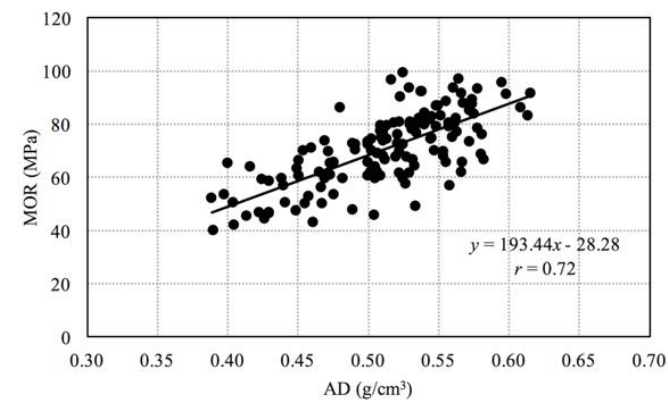

Figure 2. Relationship between air-dry density $(A D)$ and modulus of rupture (MOR) for combined ages

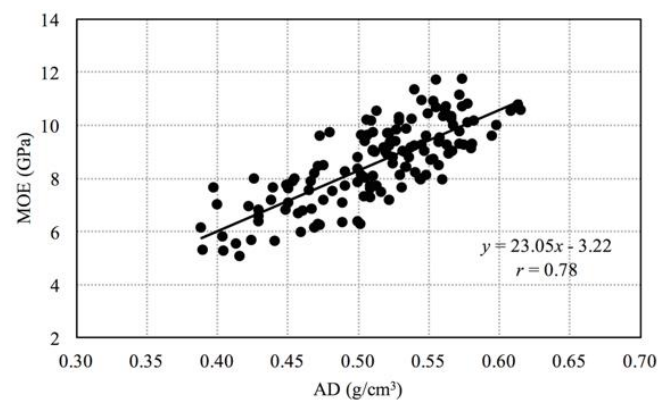

Figure 3. Relationship between air-dry density $(A D)$ and modulus of elasticity (MOE) for combined ages

Wood density is an important indicator of the static bending strength properties of wood. The present results are comparable with those reported by Makino et al. [4] who found the positive correlation of basic density with mechanical properties of A. mangium planted in Indonesia. In other hardwood species, Duong and Matsumura [13] found strong positive correlations of AD with MOR $(r=0.84)$ and MOE $(r=0.72)$ at MC about $12 \%$ in Melia azedarach planted in Son $\mathrm{La}$, Vietnam. Positive linear relationships between $\mathrm{AD}$ and mechanical properties were also reports by Machado et al. [12] for Acacia melanoxylon wood.

\section{Conclusions}

a. Tree age had significantly affected on physical and mechanical properties investigated in this study. AD, MOR, and MOE increased rapidly from age 7 to age 10 before stabilizing to age 14 .

b. In radial direction, $\mathrm{AD}, \mathrm{MOR}$, and MOE were lower near the pith and higher near the bark in all age levels. In 10- and 14-year-old, wood properties determined in this study increased considerably from pith to the middle position before remaining constant value forward to outside.

c. AD had a significant positive linear relationship with mechanical properties (MOR, MOE). Therefore, $\mathrm{AD}$ can be considered to be a powerful indicator for predicting the static bending strength of A. mangium planted in Thai Nguyen. 


\section{REFERENCES}

[1] H. H. Phi, "Genetic control on wood mechanical properties of Acacia mangium in the second generation progenytests," Science and Technology Journal of Agriculture and Rural Development, vol. 14, pp. 128-135, 2018.

[2] Ministry of Agriculture and Rural Development, The list of major forest plant species, recognition of varieties and seed sources, management of materials of major forest plant varieties. No. 30/2018/TTBNNPTNT, Ha Noi, 2018.

[3] H. M. Trinh, "Effect of harvested age on some physical and mechanical properties of peeled veneer from Acacia mangium Willd.," Journal of Forestry Science and Technology, vol. 6, pp. 134-141, 2018.

[4] K. Makino, F. Ishiguri, I Wahyudi, Y. Takashima, K. Iizuka, S. Yokota, and N. Yoshizawa, "Wood properties of young Acacia mangium trees planted in Indonesia," Forest Product Journal, vol. 62, no. 2, pp. 102-106, 2012.

[5] M. Q. Chowdhury, M. I. Shams, and M. Alam, "Effects of age and height variation on physical properties of mangium (Acacia mangium Willd.) wood," Australian Forestry, vol. 68, no. 1, pp. 17-19, 2005.

[6] V. D. Duong, T. T. H. Tran, T. K. H Duong, T. Y. Trieu, and D. T. Nguyen, "Variation in wood density and mechanical properties of Manglietia conifera Dandy planted in $\mathrm{Na} \mathrm{Ri}$, Bac Kan," Journal of Forestry Science and Technology, vol. 9, pp. 121-126, 2020.

[7] R Core Team, "R: A language and environment for statistical computing," R Foundation for Statistical Computing, Vienna, Austria. [Online]. Available: https://www.R-project.org. [Accessed Sept. 01, 2020].

[8] T. K. Nguyen, M. Ochiishi, J. Matsumura, and K. Oda, "Variation in wood properties of six natural acacia hybrid clones in northern Vietnam," Journal of Wood Science, vol. 54, pp. 436-442, 2008.

[9] I. Wahyudi, F. Ishiguri, K. Makino, H. Aiso, Y. Takashima, J. Ohshima, H. Iizuka, and S. Yokota, "Evaluation of xylem maturation and the effects of radial growth rate on anatomical characteristics and wood properties of Azadirachta excelsa planted in Indonesia," Journal of the Indian Academy of Wood Science, vol. 13, no. 2, pp. 138-144, 2016.

[10] M. H. Sahri, Z. Ashaari, R. A. Kader, and A. L. Mohmod, "Physical and mechanical properties of Acacia mangium and Acacia auriculiformis from different provenances," Pertanika Journal of Tropical Agricultural Science, vol. 21, no. 2, pp. 73-81, 1998.

[11] T. Fujimoto, H. Akutsu, and T. Takizawa, "Several wood properties of plantation-grown Acacia species," Journal of th Hokkaido Forest Products Research Institute, vol. 16, no. 2, pp. 6-10, 2002.

[12] J. L. Machado, J. L. Louzada, A. J. A. Santos, L. Nunes, O. Anjos, J. Rodrigues, R. M. S. Simoes, and H. Pereira, "Variation of wood density and mechanical properties of blackwood (Acacia melanoxylon R. Br.)," Materials and Design, vol. 56, pp. 975-980, 2014.

[13] V. D. Duong, and J. Matsumura, "Within-stem variations in mechanical properties of Melia azedarach planted in northern Vietnam," Journal of Wood Science, vol. 64, pp. 329-337, 2018. 